\title{
Tyrosine $\boldsymbol{O}$-Sulphate in Fibrinogen and Fibrin
}

\author{
By F. R. JEVONS \\ Department of Chemistry, University of Manchester
}

(Received 24 June 1963)

This paper describes the details of the identification and determination of tyrosine $O$-sulphate in fibrinogen, fibrin and fibrinopeptide $B$, as already reported in preliminary communications by the author under his previous names (Bettelheim, 1954; Bettelheim-Jevons, 1958).

The first indication of the presence of tyrosine in modified form came during work on the peptides liberated from bovine fibrinogen during clotting by thrombin (Bailey \& Bettelheim, 1955; Bettelheim, 1956). One of these peptides, fibrinopeptide $B$, was found to give rise to tyrosine on acid hydrolysis; yet the peptide showed no trace of the absorption peaks at 275 and $293 \mathrm{~m} \mu$ characteristic of tyrosine in neutral and alkaline solution respectively. Further, after dinitrophenylation of the peptide with 1fluoro-2,4-dinitrobenzene, acid hydrolysis gave rise to free tyrosine and not its $O$-dinitrophenyl derivative. Some group, therefore, blocks the phenolic hydroxyl group of tyrosine in the intact peptide. This group was found to be readily removed by acid but not by alkali. Marked lability to acid and stability to alkali is characteristic of aryl sulphates, and the presence of tyrosine $O$-sulphate was confirmed as described below. Further, development of a method for determining tyrosine $O$-sulphate even in the presence of a large excess of tyrosine made it possible to show its presence also in fibrinogen and fibrin from various mammalian species.

Tyrosine $O$-sulphate is excreted in considerable amounts in human urine (Tallan, Bella, Stein \& Moore, 1955). The incorporation of inorganic [ $\left.{ }^{35} \mathrm{~S}\right]$ sulphate into the tyrosine $O$-sulphate residue of fibrinopeptide B has been demonstrated (Blombäck, Boström \& Vestermark, 1960), and the metabolic fate of this residue has been studied (Jones, Dodgson, Powell \& Rose, 1963).

\section{EXPERIMENTAL}

Materials. Bovine fibrinogen was prepared from fresh citrate-treated ox plasma. Preparation 1 was purified by five precipitations with solid ammonium sulphate to $20 \%$ saturation, redissolving the precipitate in each case at an ionic strength of $\mathbf{0 . 5}$. As measured spectrophotometrically at $280 \mathrm{~m} \mu, 96 \%$ of the protein was clottable by thrombin. Preparation 2 (94\% clottable) was obtained by two precipitations with an equal volume of $2 \mathrm{M}$-potassium phosphate buffer, pH $6 \cdot 8$ (Jaques, 1943).
Horse fibrinogen ( $80 \%$ clottable) was obtained from fresh citrate-treated horse plasma by two precipitations with ammonium sulphate as described above.

Bovine and horse fibrin were prepared by clotting the corresponding fibrinogens with thrombin as described by Bailey \& Bettelheim (1955).

Human fibrin, obtained by clotting highly purified fibrinogen, was a gift from Dr R. A. Kekwick.

Bovine fibrinopeptide B was prepared by column chromatography as described by Bettelheim (1956).

Paper chromatography. The solvent systems used are designated as follows: $I$, butanol-acetic acid-water $(4: 1: 5$, by vol.) (Partridge, 1948); II, phenol-aq. $0.3 \% \mathrm{NH}_{3}-\mathrm{HCN}$ (Consden, Gordon \& Martin, 1944); III, $60 \%$ (v/v) acetone containing $0.5 \%$ of urea (Bentley \& Whitehead, 1950). Ascending chromatography was used for system III.

Synthesis of tyrosine O-sulphate. Tyrosine was sulphated with sulphuric acid at low temperature (cf. Reitz, Ferrel, Fraenkel-Conrat \& Olcott, 1946). Tyrosine (2 g.) was stirred with $20 \mathrm{~g}$. of conc. $\mathrm{H}_{2} \mathrm{SO}_{4}$ at $-5^{\circ}$ for $30 \mathrm{~min}$. The product was poured into a mixture of ice and excess of $\mathrm{Ba}(\mathrm{OH})_{2}, \mathrm{BaSO}_{4}$ was filtered off and remaining barium was precipitated by adding solid $\mathrm{CO}_{2}$. The filtrate was evaporated to dryness under reduced pressure, and the residue extracted with cold water. Unchanged tyrosine was filtered off, and the solution was passed through a column of Dowex 50 (X4; $\mathrm{H}^{+}$form) and then brought to $\mathrm{pH} 5$ with $\mathrm{N}-\mathrm{KOH}$. The addition of ethanol and ether gave an amorphous precipitate that soon crystallized as fine needles. The product was dried over $\mathrm{NaOH}$ and $\mathrm{P}_{2} \mathrm{O}_{5}$ at room temperature. The yield was $0 \cdot 3 \mathrm{~g}$. Analysis showed the product to be the monohydrate of the potassium salt (Found: C, 34.0; H, 3.86; S, 10.1. $\mathrm{C}_{9} \mathrm{H}_{10} \mathrm{KNO}_{6} \mathrm{~S}, \mathrm{H}_{2} \mathrm{O}$ requires $\mathrm{C}, 34 \cdot 1 ; \mathrm{H}, 3 \cdot 79 ; \mathrm{S}, 10 \cdot 1 \%$ ). Tallan et al. (1955) reported crystals of the dihydrate.

The crystalline product gave less than $2 \%$ of the colour yield of an equimolar amount of tyrosine with the phenol reagent of Folin \& Ciocalteu (1929) (British Drug Houses Ltd.). It gave single ninhydrin-positive spots on paper chromatography with all systems tested, the $R_{F}$ values being approximately $0.2,0.4$ and 0.7 in systems I, II and III respectively. A non-crystalline product obtained by treating tyrosine with $\mathrm{H}_{2} \mathrm{SO}_{4}$ showed, in addition to the tyrosine $O$-sulphate spot, a smaller component moving more slowly in system I. This component was acidstable and was presumably a sulphonate (cf. Reitz et al. 1946).

Determination of inorganic sulphate. Free sulphate was determined turbidimetrically after the addition of $\mathrm{Ba}^{2+}$ ions. Preliminary trials were made with the polyoxyethylene lauryl alcohol detergent BRIJ 35 (Atlas Powder Co., Wilmington, Del., U.S.A.) as protective colloid. Conditions were found under which linear calibration curves could be obtained, but the results were much affected by 
the presence of small quantities of protein. Gelatin was therefore substituted for BRIJ 35.

The method used was as follows. To the sample in $0.3 \mathrm{ml}$. of $\mathrm{N}$-HCl were added $0.15 \mathrm{ml}$. of $4 \mathrm{~N}$-sodium acetate, $0.75 \mathrm{ml}$. of $95 \%(v / v)$ ethanol and $1 \cdot 3 \mathrm{ml}$. of water. The solution was well mixed before and immediately after adding $0.5 \mathrm{ml}$. of a reagent containing $0.5 \%$ of gelatin (U.S.P.) and $1 \%(w / v)$ of barium acetate. The extinction was measured at $340 \mathrm{~m} \mu$ after $30 \mathrm{~min}$. Readings were stable within $2 \%$ up to $2 \mathrm{hr}$. Calibration curves, constructed with known amounts of ammonium sulphate containing 2 to $20 \mu \mathrm{g}$. of sulphur, were linear and passed through the origin. The addition of $1 \mathrm{mg}$. of bovine serum albumin changed the readings by only $2-3 \%$, but $0.6 \mathrm{mg}$. of fibrinopeptide $B$ raised them by $10-30 \%$.

Determination of tyrosine O-sulphate in proteins. The protein sample $(50-300 \mathrm{mg}$.) was heated with $1 \mathrm{ml}$. of water and $1 \mathrm{~g}$. of $\mathrm{Ba}(\mathrm{OH})_{2}, 8 \mathrm{H}_{2} \mathrm{O}$ in a sealed tube at $110^{\circ}$ for various times as indicated. The contents were washed out with water and shaken mechanically for $1 \mathrm{hr}$. with a moderate excess of Dowex $50\left(\mathrm{H}^{+}\right.$form). After the resin had been filtered off, the filtrate was made alkaline with ammonia, concentrated under reduced pressure and made up to $5 \cdot 0 \mathrm{ml}$.

Tyrosine $O$-sulphate in the resulting solutions was determined by measuring the increment in 'phenol' colour produced by acid hydrolysis. Duplicate $0.5 \mathrm{ml}$. samples were mixed with $0.5 \mathrm{ml}$. of $\mathrm{N}-\mathrm{HCl}$ and heated at $100^{\circ}$ for $10 \mathrm{~min}$. Colour was developed by adding $2 \mathrm{ml}$. of $2 \mathrm{~N}$ $\mathrm{NaOH}$ followed by $1 \mathrm{ml}$. of Folin-Ciocalteu reagent (diluted with 3 vol. of water) and water to $6.0 \mathrm{ml}$. The extinction at $600 \mathrm{~m} \mu$ was measured after $5 \mathrm{~min}$; alternatively, the blue colour was measured in an EEL colorimeter (Evans Electroselenium Ltd.) with filter 205. From the values obtained were deducted those for similar $0.5 \mathrm{ml}$. samples treated in the same way except for the omission of the heating step. The difference was taken to be due to tyrosine liberated by hydrolysis of its sulphate. Calibration curves were constructed with 5 to $50 \mu \mathrm{g}$. of tyrosine.

Shaking with Dowex $50\left(\mathrm{H}^{+}\right.$form) was more convenient than passage through a column of the resin when a number of samples were handled simultaneously. Moreover, considerable losses were observed when solutions containing tyrosine $O$-sulphate were washed through such columns with water.

\section{RESULTS}

Ultraviolet absorption of fibrinopeptide $B$ and tyrosine O-sulphate before and after acid hydrolysis. The absorption spectrum of a solution of fibrinopeptide $B$ in water $(0.33 \mathrm{mg} . / \mathrm{ml}$.) showed no tyrosine peak near $275 \mathrm{~m} \mu$, but only weak absorption with a flat maximum near $260 \mathrm{~m} \mu\left(E_{1 \mathrm{~cm}}=0.06\right)$. In $0 \cdot 1 \mathrm{~N}$-sodium bydroxide there was no tyrosine peak at $293.5 \mathrm{~m} \mu, E_{1 \mathrm{~cm}}$. at this wavelength being only $\mathbf{0 . 0 1 8}$. After hydrolysis in N-hydrochloric acid for $10 \mathrm{~min}$. at $100^{\circ}$, however, the characteristic tyrosine absorption was observed. Calculation of the amount of tyrosine from the extinction at $293.5 \mathrm{~m} \mu$ in $0.1 \mathrm{~N}$-sodium hydroxide, by taking $\epsilon$ to be $2 \cdot 33 \times 10^{3}$ (Beaven \& Holiday, 1952), gave values of $2500 \mathrm{~g}$. and $2800 \mathrm{~g}$. in two separate experiments for the amounts of fibrinopeptide $B$ giving rise to 1 mole of tyrosine. Since the molecular weight of the peptide is 2460 (Gladner, Folk, Laki \& Carroll, 1959), this indicates the presence of one tyrosine residue/molecule.

Tyrosine $O$-sulphate in $0 \cdot 1 \mathrm{~N}$-sodium hydroxide showed relatively weak absorption with a flat maximum near $263 \mathrm{~m} \mu\left(\epsilon=4.2 \times 10^{2}\right)$. At $293.5 \mathrm{~m} \mu$ the extinction was only $2 \%$ that of an equimolar amount of tyrosine. The quantity of tyrosine formed on acid hydrolysis, determined spectrophotometrically as above, was $102 \%$ of that calculated. The liberation of tyrosine was $62 \%$ complete after $2 \mathrm{~min}$., and $92 \%$ complete after $5 \mathrm{~min}$., in $0.5 \mathrm{~N}$-hydrochloric acid at $100^{\circ}$.

Liberation of inorganic sulphate. The formation of inorganic sulphate by mild acid hydrolysis of fibrinopeptide $\mathrm{B}$ was shown by adding $\mathrm{Ba}^{2+}$ ions. Determination of the amount liberated after $10 \mathrm{~min}$. in $\mathrm{N}$-hydrochloric acid at $100^{\circ}$ gave values ranging from 0.9 to $1.5 \mathrm{moles} / \mathrm{mole}$ of tyrosine. The fact that the values are higher than predicted can perhaps be partly explained by the unduly high results given by the turbidimetric method in the presence of fibrinopeptide B (see the Experimental section).

Table 1 shows that the time-course of the liberation of inorganic sulphate runs parallel to that of the liberation of the phenolic group of tyrosine.

Detection of tyrosine O-sulphate in alkaline hydrolysates. Fibrinopeptide B (4 mg.) was heated in $1 \mathrm{ml}$. of $0.2 \mathrm{~N}$-barium hydroxide at $125^{\circ}$ for $24 \mathrm{hr}$. in a sealed tube. After the removal of other amino acids with Dowex 50 ( $\mathrm{H}^{+}$form), paper chromatography showed the presence of a single ninhydrinpositive component identical with tyrosine $O$ sulphate in systems I, II and III. The yield, estimated by spot dilution on paper chromatograms and also spectrophotometrically as tyrosine after

\section{Table 1. Parallel liberation of inorganic sulphate and phenolic group from fibrinopeptide $B$}

Samples (2.0 mg.) of fibrinopeptide B in $\mathbf{0 . 3} \mathrm{ml}$. of $\mathrm{N}-\mathrm{HCl}$ were heated as shown. The liberation of phenolic group was measured by the extinction at $275 \mathrm{~m} \mu$, and inorganic sulphate was then determined turbidimetrically in the same solutions. Experimental details are given in the text.

$\begin{array}{ccc}\text { Free } & \\ \begin{array}{c}\text { Heat treatment } \\ \text { in } \mathrm{N}-\mathrm{HCl}\end{array} & \begin{array}{c}\text { phenolic group } \\ \text { (\% of }\end{array} & \begin{array}{c}\text { Free sulphate } \\ \text { (\% of } \\ \text { maximum value) }\end{array} \\ \begin{array}{c}\text { maximum value) } \\ \text { min. at } 75^{\circ}\end{array} & 11 & 19 \\ 6 \text { min. at } 75^{\circ} & 46 & 52 \\ 2 \text { min. at } 93^{\circ} & 65 & 60 \\ 4 \text { min. at } 93^{\circ} & 100 & 97 \\ 10 \text { min. at } 93^{\circ} & 99 & 100\end{array}$


acid hydrolysis, was about $75 \%$ of that expected from the tyrosine content of the peptide.

For the identification of tyrosine $O$-sulphate in bovine fibrinogen, $200 \mathrm{mg}$. of preparation 2 (prepared by precipitation with potassium phosphate and not ammonium sulphate) was used. After heating with barium hydroxide and treatment with Dowex $50\left(\mathrm{H}^{+}\right.$form) as described in the Experimental section, too much solid matter remained in the solution for successful paper chromatography. The solution was applied to a small column of activated charcoal (British Drug Houses Ltd.), which was washed with 2 column volumes of water before elution with 2 column volumes of $20 \%(\mathrm{v} / \mathrm{v})$ pyridine. The major ninhydrin-positive component in the pyridine eluate ran at the same rate as authentic tyrosine $O$-sulphate on paper chromatography (system I). Its identity with the latter was further confirmed by showing that it released free tyrosine at the same rate during hydrolysis in $0.5 \mathrm{~N}$-hydrochloric acid at $100^{\circ}$.

Similar results were obtained with a preparation of horse fibrinogen obtained by two precipitations with potassium phosphate. Only $50 \%$ of the

\section{Table 2. Destruction of tyrosine O-sulphate in alkali}

Samples $(500 \mu \mathrm{g}$.) of tyrosine $O$-sulphate were heated at $110^{\circ}$ in sealed tubes with $1 \mathrm{ml}$. of water, $1 \mathrm{~g}$. of $\mathrm{Ba}(\mathrm{OH})_{2}$,$8 \mathrm{H}_{2} \mathrm{O}$, and zein as indicated. Recoveries of tyrosine $O$-sulphate were then determined as described in the Experimental section.

$\begin{array}{ccc}\begin{array}{c}\text { Period of } \\ \text { heating } \\ \text { (hr.) }\end{array} & \begin{array}{c}\text { Zein } \\ \text { added } \\ \text { (mg.) }\end{array} & \begin{array}{c}\text { Recovery } \\ (\%)\end{array} \\ 7 & 200 & 94 \\ 15 & 200 & 70 \\ 16 & 200 & 74 \\ 40 & 200 & 51 \\ 39 & 0 & 60\end{array}$

protein in this preparation was clottable by thrombin, however.

Determination of tyrosine O-sulphate in fibrinogen and fibrin. Direct spectrophotometric measurement of phenolic group liberated by acid, as used for fibrinopeptide B, was not suitable as a method for determining tyrosine $O$-sulphate in fibrinogen and fibrin, where the sulphate occurs in small amounts much overshadowed by tyrosine unsubstituted at the hydroxyl group, as well as by tryptophan. The method developed for use in such cases, as described in the Experimental section, involves the following stages: (a) hydrolysis with barium hydroxide to liberate tyrosine $O$-sulphate from peptide combination; (b) treatment with Dowex 50 ( $\mathrm{H}^{+}$form) to remove most of the other amino acids; $(c)$ measurement of the increment produced by acid hydrolysis in the 'phenol' colour given with the FolinCiocalteu reagent.

To estimate destruction of tyrosine $O$-sulphate during the alkaline hydrolysis, known amounts $(500 \mu \mathrm{g}$.) were heated in barium hydroxide solution with and without the addition of the protein zein. Recoveries are shown in Table 2. By using these values as a basis, correction factors were estimated to apply to the amounts of tyrosine $O$-sulphate obtained from samples of fibrinogen and fibrin. From the corrected values, weights of protein estimated to contain 1 mole of tyrosine $O$-sulphate were calculated and are shown in Table 3.

Search for tyrosine O-sulphate in other proteins. The above method was applied to the following proteins: rabbit tropomyosin $(240 \mathrm{mg}$.), rabbit myosin (290 mg.), rabbit actin (110 mg.), porcupine-quill keratin (190 mg:), bovine serum albumin (200 mg.), horse globin (200 mg.), egg albumin (200 mg.), gelatin (200 mg.), zein (200 mg.), growth hormone (50 mg.) and prolactin (200 mg.). In no case was any indication obtained of the presence of tyrosine $O$-sulphate in significant amounts.

Table 3. Tyrosine O-sulphate contents of fibrinogens and fibrins

A sample (200 mg.) of air-dried protein, corresponding to $176 \mathrm{mg}$. of protein dried at $100^{\circ}$, was used in each case. Experimental details are given in the text.

\begin{tabular}{l}
\multicolumn{1}{c}{ Protein } \\
Bovine fibrinogen (prep. 1) \\
Bovine fibrinogen (prep. 1) \\
Bovine fibrinogen (prep. 1) \\
Bovine fibrin (prep. 1) \\
Bovine fibrin (prep. 1) \\
Bovine fibrin (prep. 1) \\
Bovine fibrinogen (prep. 2) \\
Horse fibrinogen \\
Horse fibrin \\
Human fibrin
\end{tabular}

Protein

Bovine fibrinogen (prep. 1)

Bovine fibrinogen (prep. 1 )

Bovine fibrin (prep. 1)

Bovine fibrin (prep. 1)

Bovine fibrin (prep. 1)

Horse fibrin

\begin{tabular}{|c|}
\hline $\begin{array}{l}\text { Length of } \\
\text { alkaline } \\
\text { hydrolysis } \\
\text { (hr.) }\end{array}$ \\
\hline 10 \\
\hline 16 \\
\hline 28 \\
\hline 10 \\
\hline 16 \\
\hline 28 \\
\hline 16 \\
\hline 40 \\
\hline 40 \\
\hline \\
\hline
\end{tabular}

Tyrosine

-sulphate

found

(as $\mu \mathrm{g}$. of
tyrosine)

$$
190
$$

176

158

88

97

77

195

245

120

105
Destruc- tion containing assumed 1 mole

(\%) (g.)

- $\quad \overline{1.4}$

$40 \quad 1.2$

-

25

40

25

50

50

50

$\begin{gathered}10^{-5} \times W t . \\ \text { of protein } \\ \text { containing } \\ 1 \text { mole }\end{gathered}$
$(\mathrm{g}$.
-
$1 \cdot 4$
$1 \cdot 2$
$\overline{2 \cdot 5}$
$2 \cdot 5$
$1 \cdot 2$
$0 \cdot 65$
$1 \cdot 3$
$1 \cdot 5$




\section{DISCUSSION}

In outline, the evidence for the occurrence of tyrosine $O$-sulphate in bovine fibrinopeptide $\mathrm{B}$ is as follows: (1) In the intact peptide, the phenolic group of tyrosine is blocked, as shown by absence of the characteristic ultraviolet absorption and by lack of reactivity with 1 -fluoro-2,4-dinitrobenzene. (2) The blocking group is readily removed by mild acid hydrolysis, during which phenolic group and inorganic sulphate are liberated in equimolar amounts and at parallel rates. (3) Alkaline hydrolysates contain a component chromatographically identical with synthetic tyrosine $O$-sulphate.

Tyrosine $O$-sulphate was also detected in fibrin. Not all the tyrosine $O$-sulphate of fibrinogen, therefore, is liberated in the peptide material set free during clotting by thrombin.

Most of the proteins used were purified by precipitation with ammonium sulphate, and the possibility was therefore considered that tyrosine $O$-sulphate arises by reaction of some other reactive tyrosine derivative with inorganic sulphate. Tyrosine $O$-sulphate was also obtained, however, from preparations of bovine and horse fibrinogen precipitated with potassium phosphate in place of ammonium sulphate; it was identified by paper chromatography and by the rate of release of tyrosine in acid. It appears, therefore, to be a genuine constituent of these proteins.

As far as the available evidence goes, the occurrence of tyrosine $O$-sulphate in proteins is restricted to fibrinogens and their degradation products. None was detected in a number of other proteins examined.

On the quantitative side, some doubt remains about the exact tyrosine $O$-sulphate contents of fibrinogens and fibrins, which are very low (about $0 \cdot 1-0.5 \%$ by wt.). The main source of uncertainty is the degree of destruction during alkaline hydrolysis. Recovery experiments in which tyrosine $O$-sulphate is heated with alkali in the presence of protein make it possible to allow for the influence of protein constituents on the rate of destruction, but they give no information about any differences in stability between free and peptide-bound tyrosine $O$-sulphate.

With bovine fibrinogen, the best estimate can probably be obtained by relying on other quantitative data which show that two molecules of fibrinopeptide B are formed from each molecule of fibrinogen (Blombäck \& Yamashina, 1958), coupled with the fact that the tyrosine $O$-sulphate content of fibrin seems to be half that of fibrinogen (Table 3). Fibrinogen (mol.wt. 330000; see Scheraga \& Laskowski, 1957) thus probably contains four residues of tyrosine $O$-sulphate/molecule, two of which are split off in fibrinopeptide B during clotting while two remain in fibrin.

More tyrosine $O$-sulphate was found in horse fibrin and human fibrin than in bovine fibrin. With horse fibrin, the tyrosine $O$-sulphate content seems again to be half that of fibrinogen. With human fibrin, however, it has been reported that no tyrosine $O$-sulphate is present in the peptide material released on clotting (Korff \& Bronfenbrenner, 1958), although serine phosphate has been found (Blombäck, Blombäck, Edman \& Hessel, 1962).

\section{SUMMARY}

1. Tyrosine $O$-sulphate has been identified as a constituent of bovine fibrinopeptide $\mathrm{B}$, fibrinogen and fibrin.

2. A method has been devised for determining small proportions of tyrosine $O$-sulphate in proteins. Values are given for fibrinogen and fibrin from ox and horse, and for human fibrin.

3. No tyrosine $O$-sulphate was detected in any other protein examined.

\section{REFERENCES}

Bailey, K. \& Bettelheim, F. R. (1955). Biochim. biophys. Acta, 18, 495.

Beaven, G. H. \& Holiday, E. R. (1952). Advanc. Protein Chem. 7, 323.

Bentley, H. R. \& Whitehead, J. K. (1950). Biochem. J. 46, 341.

Bettelheim, F. R. (1954). J. Amer. chem. Soc. 76, 2838.

Bettelheim, F. R. (1956). Biochim. biophys. Acta, 19, 121.

Bettelheim-Jevons, F. R. (1958). Abstr. Commun. 4th int. Congr. Biochem., Vienna, no. 1725, p. 201.

Blombäck, B., Blombäck, M., Edman, P. \& Hessel, B. (1962). Nature, Lond., 193, 884.

Blombäck, B., Boström, H. \& Vestermark, A. (1960). Biochim. biophys. Acta, 38, 502.

Blombäck, B. \& Yamashina, I. (1958). Ark. Kemi, 12, 299.

Consden, R., Gordon, A. H. \& Martin, A. J. P. (1944). Biochem. J. 38, 224.

Folin, O. \& Ciocalteu, V. (1929). J. biol. Chem. 73, 627.

Gladner, J. A., Folk, J. E., Laki, K. \& Carroll, W. R. (1959). J. biol. Chem. 234, 62.

Jaques, L. B. (1943). Biochem. J. 37, 344.

Jones, J. G., Dodgson, K. S., Powell, G. M. \& Rose, F. A. (1963). Biochem. J. 87, 548.

Korff, R. W. von \& Bronfenbrenner, A. (1958). J. Amer. chem. Soc. 80, 5575.

Partridge, S. M. (1948).' Biochem. J. 42, 238.

Reitz, H. C., Ferrel, R. E., Fraenkel-Conrat, H. \& Olcott, H. S. (1946). J. Amer. chem. Soc. 68, 1024.

Scheraga, H. A. \& Laskowski, M., jun. (1957). Advanc. Protein Chem. 12, 1.

Tallan, H. H., Bella, S. T., Stein, W. H. \& Moore, S. (1955). J. biol. Chem. 217, 703. 